\title{
EFFECTS OF THE DIFFERENT IMPLEMENTATION OF LEGISLATION RELATING TO SEWAGE SLUDGE DISPOSAL IN THE EU
}

\author{
Torben Bauer ${ }^{1, \star}$, Linus Ekman Burgman ${ }^{2}$, Lale Andreas ${ }^{1}$ and Anders Lagerkvist ${ }^{1}$ \\ ${ }^{1}$ Waste Science and Technology, Luleå University of Technology, 97187 Luleå, Sweden \\ 2 Technology and Social Change, Linköping University, 58183 Linköping, Sweden
}

Article Info:
Received:
13 December 2019
Revised:
3 March 2020
Accepted:
5 March 2020
Available online:
8 May 2020
Keywords:
Sewage sludge
Legislation
Phosphorus recovery
Nutrient recovery
Land application

\section{INTRODUCTION}

Sewage sludge is produced in wastewater treatment plants. The sludge acts concomitantly as a sink for pollutants (toxic elements, organic contaminants, pathogens, residues of pharmaceuticals, micro plastic) and the stream, which accumulates organic matter and nutrients in the wastewater stream. In the EU-27, based on a 2005 calculation, 9.8 MtDS/year of sewage sludge were produced (Kelessidis \& Stasinakis, 2012). By 2020, the amount of sewage sludge was expected to exceed $13 \mathrm{MtDS} /$ year in the EU-27 following implementation of the Urban Waste Water Treatment Directive in member states joining the EU subsequent to 2004 (Kelessidis \& Stasinakis, 2012). Currently, the main method applied in the treatment of sewage sludge is anaerobic digestion, which makes use of approx. $50 \%$ of the organic matter by producing biogas and partly addresses the issue of pollutants (Kelessidis \& Stasinakis, 2012). Following anaerobic digestion, the sewage sludge is disposed of or reused in a series of different ways. The main re-use route in the EU is application on agricultural soil (45\% directly and $7 \%$ after composting of the produced sludge (LeBlanc, Matthews, \& Richard, 2008)). However, although application on agricultural soil makes use of the nutrients contained in the sludge, it also diffuses the pollutants.

In addition to application on agricultural soil, the sludge can be reused in land reclamation or landfill covers. The most common disposal routes are incineration of dried sludge and landfilling. Marine disposal of sewage sludge was banned in EU in 1998 (Council of the European Communities, 1991; Kelessidis \& Stasinakis, 2012).

Re-use and disposal routes differ considerably across the EU, particularly as the EU-Directive $86 / 278$ /EEC issued in 1986 only provides guidelines relating to the re-use and final disposal of sewage sludge. Figure 1 and Figure 2 provide an overview of the total amounts per year and capita and the disposal routes for sewage sludge in selected EU countries.

The Netherlands, Germany and Sweden were chosen for this comparative study in view of their objective to minimise or abolish the use of sludge in agriculture whilst continuing to re-use the valuables contained in the sludge. Accordingly, legislation in these countries is required to identify solutions for the disposal or elimination of pollutants, whilst allowing for re-use of valuables. This conflict 
is examined herein. While the Netherlands progressed to an incineration-only strategy several years ago, Germany has also recently adhered to this trend and is currently reducing the share of land application in favour of incineration. Although Figure 2 shows a different approach in Sweden, a change from application in agriculture to incineration is also being debated in Sweden. The large share of "other" in Sweden indicates the usage of sewage sludge in landfill covers, seen as a form of land reclamation (Svinhufvud, 2017). For newer EU member countries such as Poland or Czechia, re-use and disposal routes differ widely with a focus on application in agriculture and landfilling. In the case of more recent EU-member states, it is unclear what the share of "other disposal route" represents (European Commission, 2004, 2017; Kelessidis \& Stasinakis, 2012).

The aim of this study was to highlight the differences manifested in implementation of the EU Directive 86/278/ EEC in the chosen member states. For this purpose, both
EU-level and national legislation from certain member states was analysed. The main focus was on limit values for toxic elements, as established both in the EU Directive and by national legislation, with a view to investigating how these limit values rule out certain re-use and disposal routes. In addition, the existence of limit values for organic pollutants and changes in legislation in recent years were analysed to clarify how the selected member states were attempting to improve nutrient recovery without disposing of pollutants on agricultural soil. This study was limited to the member states listed previously: the Netherlands served as an example of an incineration-only strategy; Germany was selected in the light of a recent (2017) change in legislation to promote a reduced application in agriculture and increased incineration in combination with phosphorus recovery. Finally, Sweden was chosen due to its reliance on application in agriculture, although in the presence of an ongoing policy process aimed at prohibiting all applications in agriculture whilst continuing to undertake phos-

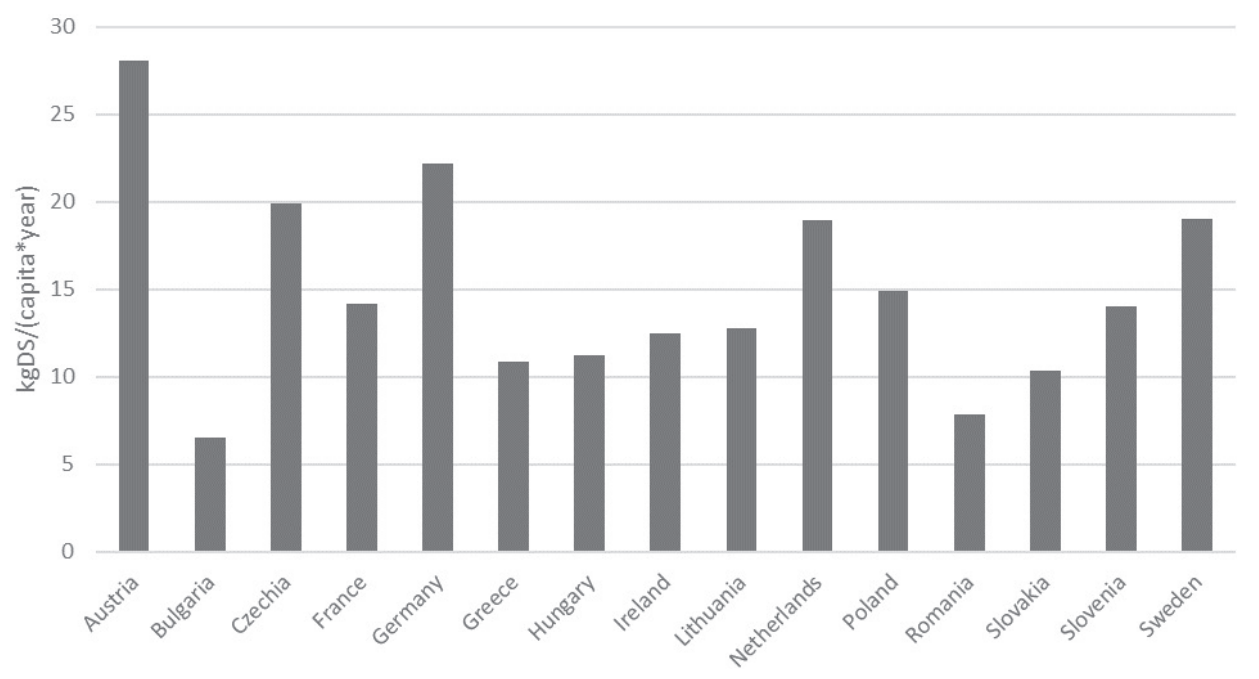

FIGURE 1: Final disposal of sewage sludge in EU countries per year and capita. Countries were selected based on the amount of sludge to be disposed of being at least 20,000 tDS/year and availability of data for either 2014 or 2015 (Eurostat, 2015).

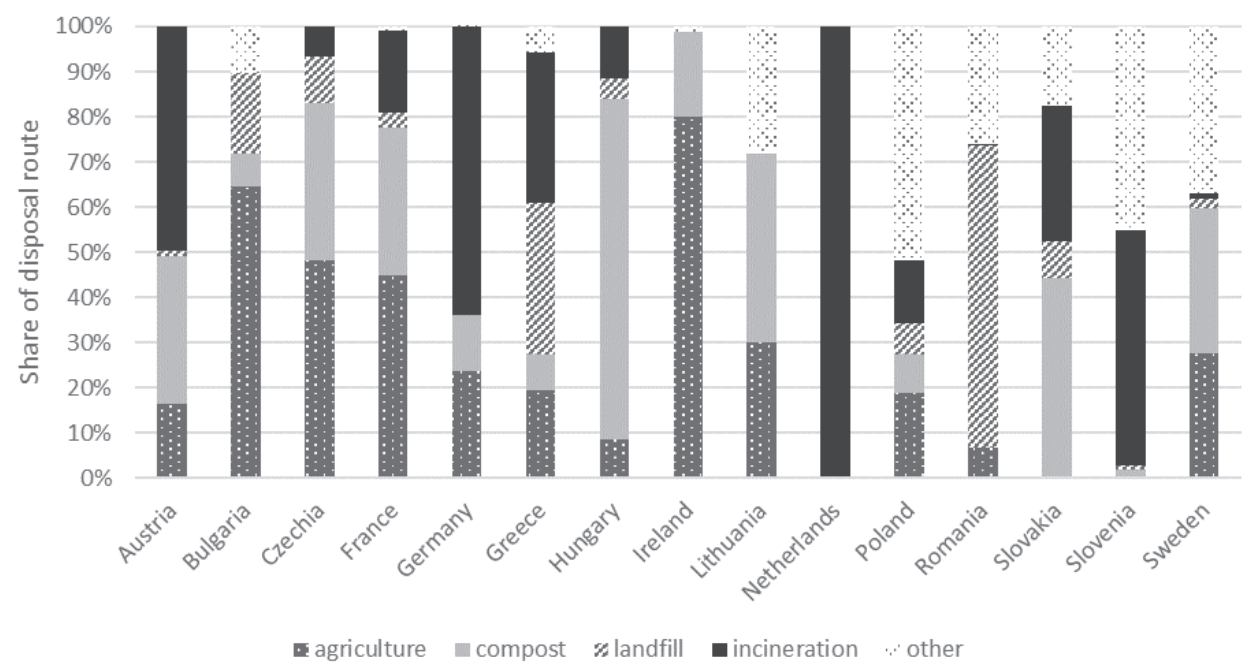

FIGURE 2: Share of each disposal route for sewage sludge in selected EU countries. Countries were selected based on the amount of sludge to be disposed of being at least 20,000 tDS/year and availability of data for either 2014 or 2015 (Eurostat, 2015). 
phorus recovery (Government Offices of Sweden, 2018a).

The aims were achieved by means of a literature review of scientific articles, reports from authorities and legislation (laws and directives). The literature covers legislation enforced at both EU level as well as in each chosen member state. Table 1 provides an overview of the legislation assessed.

\section{BACKGROUND AND LIMITATIONS}

This study focussed on limit values and future strategies for the recovery of phosphorus from sludge. Although limit values represent a minor part of the legislation system, they form the core of the legislation, with disposal strategies being expressed in limit values in many countries. The phosphorus recovery strategies implemented in the chosen member states share the common features whereby applications in agriculture are no longer envisaged, but phosphorus is still recovered and reused. To achieve this, policy-makers develop long-term strategies which can no longer be expressed only in limit values. By analysing limit values and future phosphorus recovery strategies, assumptions relating to future sewage sludge re-use and disposal strategies in the member states can be made without the need to assess other parts of the legislation.

This paper did not take into account comparisons between the fertilising qualities of sludge, sludge based fertilizers and other commercial fertilizers. Phosphorus recovery was only addressed in terms of legislation strategies and no analysis of strategies focussing on circular phosphorus flows was conducted. Accordingly, no conclusions can be drawn with regard to the importance of phosphorus recovery strategies in, for example, a circular economy.

\section{RESULTS \& DISCUSSION}

The legislation evaluated for the following chapter is shown in Table 1.

\subsection{EU}

The EU Directive 86/278/EEC dated June 1986 establishes rules and limits relating to the application of sewage sludge on agricultural soil for the purpose of recycling nutrients present in the sludge, but also limits the accumula- tion of toxic elements in the soil. The Directive suggests that member states either set limits for concentrations of toxic elements in the sludge or set accumulation limits for toxic elements in the soil. Limit values for both cases can be found in the Directive, although member states may also opt to implement stricter regulations. In addition to limiting toxic elements, the Directive regulates the documentation of sludge usage as well as providing recommendations for nutrient needs of plants, quality of soil and sludge stabilization (Brown, Tsiarta, Watson, \& Hudson, 2015; Council of the European Union, 1986a).

According to Brown (2015) the Directive has been implemented by all EU member states, with many setting stricter limits for concentrations of toxic elements in soil than the values suggested in the EU Directive (e.g. 20 member states have stricter values for $\mathrm{Cd}$ ). An even higher number of member states have set more restrictive values for concentrations of toxic elements present in sludge used in agriculture (Kelessidis \& Stasinakis, 2012). In contrast, the frequencies for soil testing vary considerably and have not been fully implemented in several member states (Brown et al., 2015).

\subsection{Netherlands}

In the Netherlands, the application of sewage sludge to agricultural soils had already been regulated prior to the introduction of the EU-Directive. In 1995, the EU-Directive was implemented into national legislation (Ruijter, 2018), and the limit values for toxic elements in soil were lower than values suggested in the EU-Directive. Even stricter values were implemented for concentrations of toxic elements in sludge $(\mathrm{Zn}, \mathrm{Cr}$, and $\mathrm{Hg}$ more than 10 times lower than in EU-Directive) (Brown et al., 2015). Since the values were much more restrictive than limit values established for other organic-based fertilizers, application in agriculture of sewage sludge became virtually impossible. Moreover, landfilling was also ruled out by setting the limit for total organic carbon in landfillable sludges below 5\% (Ehlert et al., 2013). Limit values for organic contaminants were not implemented (Ehlert et al., 2013). As changes in local legislation were foreseeable, two mono-incinerators for sewage sludge were put into operation in 1993 and 1995 (Ruijter, 2018).

TABLE 1: Overview of the legislative documents examined and specification of the literature it was accessed through.

\begin{tabular}{|c|c|c|c|}
\hline Country & Legal documents & Accessed via & Content \\
\hline EU & EU-directive 86/278/EEC & $\begin{array}{l}\text { Council of the European Union (1986) } \\
\text { and secondary literature: Brown (2015); } \\
\text { Kelessidis \& Stasinakis (2012); European } \\
\text { Commission (2004, 2017) }\end{array}$ & $\begin{array}{l}\text { Suggestions for limit values (soil, sludge, } \\
\text { dosage), application rates, re-use and } \\
\text { disposal routes }\end{array}$ \\
\hline NL & $\begin{array}{l}\text { BOOM Decree and Fertiliser Decree incl. } \\
\text { Implementation }\end{array}$ & $\begin{array}{l}\text { Secondary literature: Brown (2015); Ehlert } \\
\text { et al. (2013); de Boer et al. (2018); Ruijter } \\
\text { (2018) }\end{array}$ & Limit values (soil, sludge), application rates \\
\hline DE & $\begin{array}{l}\text { Sewage sludge ordinance (AbfKlärV) } 2015 \\
\text { and 2017; Fertilizer and Soil ordinance } \\
\text { (DüMV and BBodSchV) }\end{array}$ & $\begin{array}{l}\text { Bundesministerium für Umwelt (2015); } \\
\text { Bundesregierung (2017c, 2017a, 2017b) } \\
\text { and secondary literature: Brown (2015); van } \\
\text { Aaken (2017) }\end{array}$ & $\begin{array}{l}\text { Limit values (soil, sludge), application rates, } \\
\text { phosphorus recovery strategy, sludge han- } \\
\text { dling and transport }\end{array}$ \\
\hline SE & $\begin{array}{l}\text { Directives of Swedish environmental pro- } \\
\text { tection agency: SNFS 1994:2; SNFS 1998:4; } \\
\text { SNFS 2001:5 } \\
\text { Committee directive Dir. 2018:67 }\end{array}$ & $\begin{array}{l}\text { Government Offices of Sweden (2018); } \\
\text { Naturvårdsverket }(1994,1998,2001) \text { and } \\
\text { secondary literature: Brown }(2015) \text {; Oberg \& } \\
\text { Mason-Renton (2018) }\end{array}$ & $\begin{array}{l}\text { Limit values (soil, sludge dosage), applica- } \\
\text { tion rates (by sludge dosage) }\end{array}$ \\
\hline
\end{tabular}


Today the two mono-incinerators treat $50 \%$ of the sewage sludge produced in the Netherlands. The rest is co-incinerated in bio-energy plants, cement production, municipal solid waste incinerators and in a German coal power plant. Phosphorus removal from wastewater has been mandatory in the Netherlands since 1995 (Ruijter, 2018). Phosphorus recovery from ash is tested in the mono-incinerators. In addition, phosphorus recovery by formation of struvite in the wastewater treatment process is tested. The regulations for fertilizers in the Netherlands have a category for recovered phosphorus, making it easier for recovered phosphorus to enter the market. Since 2015, the Netherlands have legislated on phosphorus recovery, although this has proved difficult to implement (de Boer, Romeo-Hall, Rooimans, \& Slootweg, 2018).

\subsection{Germany}

In Germany, the EU-Directive was implemented through the sewage sludge ordinance in 1992. The limits in the ordinance for concentrations of toxic elements in soil and sludge were stricter in some parts than the limit values suggested by the EU-Directive. In addition, limit values for organic contaminants (polychlorinated biphenyls (PCB)) and maximum amounts for application of sludge on agricultural soil were implemented (Brown et al., 2015; Bundesministerium für Umwelt, 2015; Council of the European Union, 1986a).

The German sewage sludge ordinance was updated in 2017. The limits for toxic elements in the soil were aligned with the federal soil protection ordinance and toxic element limits for sludge were matched with those of the fertilizer ordinance. Sludge limits remained as in the previous sewage sludge ordinance. Additionally, the mixing of sludges or ashes from sludge incineration was limited and documentation requirements for sludge production, transport, incineration and disposal were intensified. The average sewage sludge in Germany continues to meet the new toxic element limits for agricultural use. In addition to the adaption of limits, a strategy for phosphorus recovery was introduced: from 2029 onwards, wastewater treatment plants with a capacity of more than 100.000 inhabitant equivalents phosphorus recovery will be mandatory if the sludge contains more than $20 \mathrm{~g}$ phosphorus per kg of sludge dry matter. For these treatment plants, application in agriculture of sludge will be forbidden from 2029 onwards. From 2032, these regulations will also apply for plants with a capacity of more than 50.000 inhabitant equivalent units. Smaller plants will not be required to recover phosphorus from sludge. Furthermore, the ordinance does not specify use of any particular technology or method for phosphorus recovery (Bundesministerium für Umwelt, 2017; Bundesregierung, 2017a, 2017b; van Aaken, 2017a).

\subsection{Sweden}

In Sweden, the EU-Directive was implemented in 1994 (Naturvårdsverket, 1994), and subsequent amendments made in 1998 and 2001 (Naturvårdsverket, 1998, 2001a). These amendments also addressed changes to the limit values of toxic elements relating to use of sewage sludge in agriculture. The Swedish legislation includes toxic ele- ment limits for both soil and applied sludge. In contrast to the legislation enforced in the Netherlands and Germany, the toxic element content of the sludge is not regulated, but rather the quantity of toxic elements to be applied to agricultural soil is limited; this implies that highly contaminated sludges may be applied in low dosages.

It should also be highlighted how following recommendation by the Swedish farmers' association that members cease all agricultural application in 1999 (Bengtsson \& Tillman, 2004), a voluntary certification, REVAQ, was established, which included stricter limit values (Malmqvist, Kärrman, \& Rydhagen, 2006). This form of limitation beyond state regulation represents the expression of a more deliberative mode of governing sewage sludge management, as seen in Sweden (Oberg \& Mason-Renton, 2018).

The Swedish government and environmental protection agency has been working to develop phosphorus recovery strategies, stricter limit values for toxic elements and new limits for organic contaminants since 2012 (Bergqvist et al., 2013; Svinhufvud, 2017). Currently, the aim is to set up a new regulation for sewage sludge disposal banning the usage of sewage sludge on land, including agriculture, although allowing for phosphorus recovery (Government Offices of Sweden, 2018b). These goals are similar to those of the new German ordinance, which will likely serve as a template for the future Swedish ordinance.

\subsection{Comparisons}

In the Netherlands, the average sewage sludge in 2012 was characterised by lower concentrations of toxic elements for all seven toxic elements tested than average sludges in Germany or Sweden (Brown et al., 2015). Swedish and German sludges are comparable in their average concentrations of toxic elements (Brown et al., 2015), whilst sludges in the Netherlands do not meet the limits for application in agriculture.

Table 2 shows a comparison of limit values for toxic elements present in sludge. In the Netherlands, the limit values for toxic elements were approx. 5-10 times stricter than values established in Germany (1992 ordinance), as shown in Figure 3. Even following introduction of the new German ordinance in 2017, limit values in the Netherlands remain considerably stricter for the majority of toxic elements compared to German values. When comparing the dose of toxic elements on agricultural soil (given as mass flows of toxic elements per area), Sweden and the Netherlands have comparable values, with Swedish values being more restrictive in part. The German values for dosage of toxic elements are approx. 15 times higher. Although Sweden and the Netherlands adhere to similar dosage limits, sewage sludge may still be applied to agricultural soil in Sweden since limit values only relate to the dosage of toxic elements (mass flow of toxic elements to the soil), and not to the total concentrations of toxic elements in the sludge.

All values throughout the three countries were at least 10 -fold, at times up to 100 -fold, lower than values suggested in the EU-Directive. In the Netherlands this was due to the fact that both accumulation of toxic elements in the soil and pollution of water bodies must be prevented (Ehlert et al., 2013). All toxic elements applied to the soil 
should be taken up by crops, resulting in no accumulation in the soil (Ehlert et al., 2013). Even for toxic elements that are not taken up by crops, accumulation should not exceed $1 \%$ over a 100-year time frame (Ehlert et al., 2013).

Table 3 shows the maximum allowable concentrations of toxic elements in soil for application of sewage sludge in agriculture. Conversely to sludge dosage values, limits for soil are in the same range for all three countries and in line with recommendations of the EU-Directive.

Since Germany is the only country of the three to have implemented limit values for organic contaminants (PCB), no comparison is possible. Although the EU included limit values for organic contaminants in their draft for a new sewage sludge directive in the year 2000, and the Swedish environmental protection agency provided suggestions for limit values on organic contaminants in 2012, neither Sweden nor the Netherlands have implemented these (Bergqvist et al., 2013; European Union, 2000). One reason for this might be that the detection of organic contaminants is more complicated than for toxic elements (Aparicio, Santos, \& Alonso, 2009). Moreover, an investigation conducted by the European Commission reported that organic contaminants (dioxins, PCBs, PAHs, TBT) should not be included in routine sewage sludge monitoring. The reason for this is that only very low quantities of organic contaminants are present in sewage sludge and have a low water solubility, thus making health problems due to leaching or plant uptake unlikely, particularly when compared to toxic elements (Langenkamp, Part, Erhardt, \& Prüeß, 2001). On the contrary, the report indeed suggests limit values for detergents (linear alkylbenzene sulphonates) for environmental reasons, ensuring the use of only aerobically and anaerobically degradable detergents (Langenkamp et al., 2001).

In all three countries, landfilling has been banned as an option for sewage sludge disposal. In the Netherlands and Germany, this has been achieved by allowing solely disposal of sludges with a TOC of less than $5 \%$. In Sweden, landfilling of organic waste is forbidden in general. In
TABLE 2: Maximum allowed amounts of toxic elements in sewage sludge which are to be applied to agricultural soil. Values for NL and DE are calculated by multiplication of limit concentrations for toxic elements in sewage sludge with maximum yearly dosage. All values are given in grams per hectare and year (g/(ha*year)). (Brown et al., 2015; Bundesministerium für Umwelt, 2015, 2017; Bundesregierung, 2017a, 2017b; Council of the European Union, 1986a; Ehlert et al., 2013; Naturvårdsverket, 2001a).

\begin{tabular}{l|c|c|c|c} 
& EU & NL & DE (2017) & SE (2001) \\
\hline $\mathrm{Cd}$ & 150 & 2.5 & 2.5 & 0.75 \\
\hdashline $\mathrm{Cr}$ & & 150 & & 40 \\
\hdashline $\mathrm{Cu}$ & 12,000 & 150 & 1503 & 300 \\
\hdashline $\mathrm{Hg}$ & 100 & 1.5 & 1.7 & 1.5 \\
\hdashline $\mathrm{Ni}$ & 3,000 & 60 & 134 & 25 \\
\hdashline $\mathrm{Pb}$ & 15,000 & 200 & 251 & 25 \\
\hline $\mathrm{Zn}$ & 30,000 & 600 & 6,680 & 600 \\
\hdashline $\mathrm{As}$ & & 30 & 67 & \\
\hdashline $\mathrm{Cr}(\mathrm{VI})$ & & & 3.3 & \\
\hline & & & & \\
\hline
\end{tabular}

TABLE 3: Maximum allowed concentrations of toxic elements in agricultural soil to which sewage sludge is to be applied. Values for Germany are dependent on physical soil properties (min: sand; max: clayey soil). Values given in $\mathrm{mg} / \mathrm{kg}$ dry matter. (Brown et al., 2015; Bundesministerium für Umwelt, 2015, 2017; Bundesregierung, 2017a, 2017b; Council of the European Union, 1986a; Ehlert et al., 2013; Naturvårdsverket, 2001a).

\begin{tabular}{|c|c|c|c|c|c|c|}
\hline & $\begin{array}{c}\text { EU } \\
\text { min. }\end{array}$ & $\begin{array}{c}\text { EU } \\
\max .\end{array}$ & NL & $\begin{array}{c}\text { DE } \\
(2017) \\
\text { min. }\end{array}$ & $\begin{array}{c}\text { DE } \\
(2017) \\
\text { max. }\end{array}$ & SE \\
\hline $\mathrm{Cd}$ & 1 & 3 & 0.8 & 0.4 & 1.5 & 0.4 \\
\hline $\mathrm{Cr}$ & & & 100 & 30 & 100 & 60 \\
\hline $\mathrm{Cu}$ & 50 & 140 & 36 & 20 & 60 & 60 \\
\hline $\mathrm{Hg}$ & 1 & 1.5 & 0.3 & 0.1 & 1 & 0.3 \\
\hline $\mathrm{Ni}$ & 30 & 75 & 35 & 15 & 70 & 30 \\
\hline $\mathrm{Pb}$ & 50 & 300 & 85 & 40 & 100 & 40 \\
\hline $\mathrm{Zn}$ & 150 & 300 & 140 & 60 & 200 & 100 \\
\hline
\end{tabular}

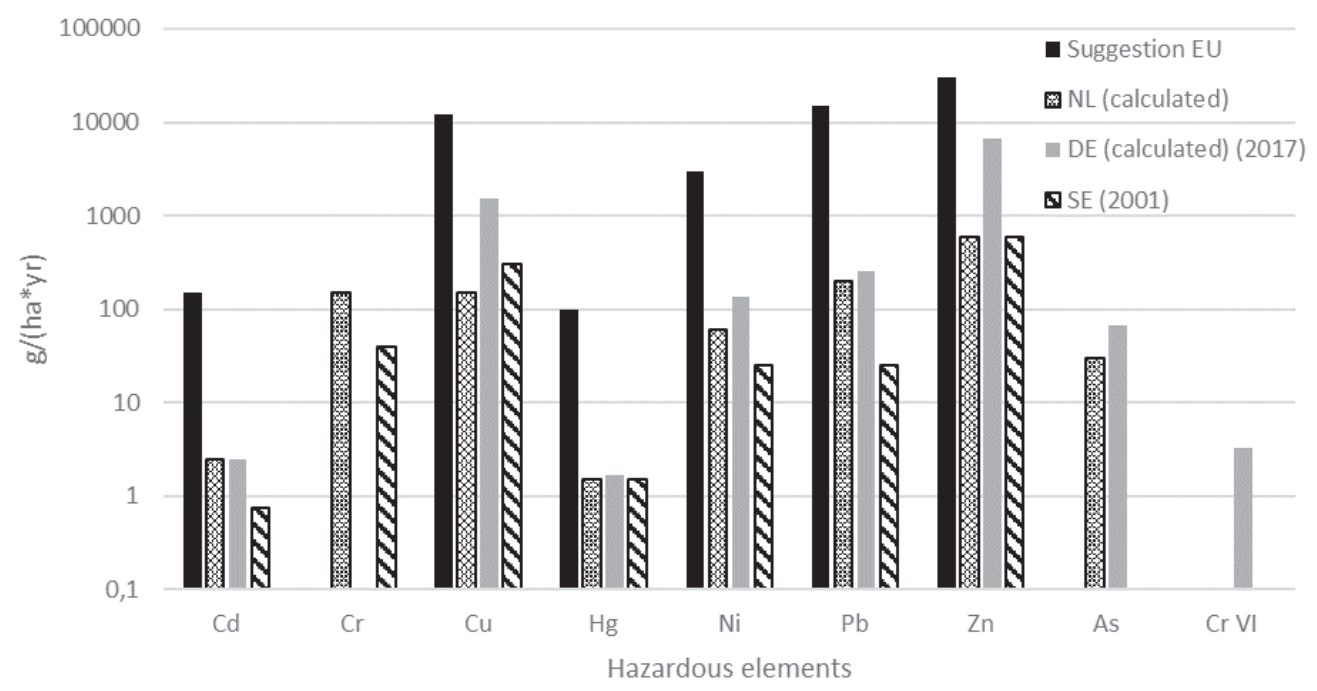

FIGURE 3: Graphical presentation of limits for concentrations of toxic elements given in Table 2 to emphasise the magnitude of differences. Note that the $y$-axis is in logarithmic scale. 
contrast to Germany and the Netherlands however, Sweden allows the usage of sewage sludge in landfill covers. Approximately a quarter of all Swedish sludge is disposed of in this way (Svinhufvud, 2017). The issue however is raised as to whether this disposal route should be viewed as a form of landfilling.

A comparison of the Dutch and German legislation clearly reveals how the focus of German authorities is on nutrient recycling, with application in agriculture as a major disposal route for sewage sludge, whereas the Netherlands have concentrated mainly on the protection of surface waters from pollutants and uncontrolled nutrient flows. Although the limits in the new German ordinance are more restrictive, application in agriculture is only partly ruled out, and most sewage sludges can still be used in agriculture. The main focus of the new ordinance is on aligning a series of German ordinances, placing more focus on documentation and testing and setting up a long term strategy for phosphorus recovery. As soon as the new phosphorus recovery strategy is in place (2029 resp. 2032) application in agriculture will be forbidden for plants to which the strategy applies.

In Sweden, the focus is directed towards keeping contamination low by implementing limits as strict as the Netherlands, although not ruling out land application of sewage sludge. Due to the strict limitations for application in agriculture of sludge in Sweden, illegal or accidental overdosage of sewage sludge on agricultural soils may occur (Zachrisson, 2019). Since the possibility of sewage sludge application has been completely precluded in the Netherlands, overdosage is impossible and illegal applications are likely to be discovered. Germany may also be prone to illegal application or overdosage, however, due to the less strict limits for application on the one hand and limit values for sludge content rather than dosage on the other, illegal application or excessive dosage are less likely. In the absence of any official data, these considerations are mainly based on assumptions; they could however represent a field of interest for further research or policymaking.

A phosphorus recovery strategy is currently being developed in Sweden, with the German strategy acting, at least in part, as a guideline for the Swedish strategy. In Sweden, a total of 416 wastewater treatment plants are currently operational (André et al., 2016), most of which are relatively small in comparison to German plants, thus highlighting how collaborations in phosphorus recovery will be crucial. Since the new German ordinance establishes limitations regulating collaborations, particularly when mixing different sludges or ashes, difficulties may be encountered in setting up these collaborations or regional networks. However, in the case of smaller wastewater treatment plants ( $<50.000$ inhabitant equivalent units) collaboration in implementing complex phosphorus recovery methods will be crucial. The latter is clearly evident in the incineration strategy of the Netherlands: although the Netherlands have 330 wastewater treatment plants, two mono-incinerators alone treat $50 \%$ of the produced sewage sludge. The implementation of phosphorus recovery strategies on the sites equipped with mono-incinerators is the most feasible means of nutrient recovery in the Netherlands (Ruijter,
2018). In Germany, a total of 9500 wastewater treatment plants are currently in operation, 9000 of which treat less than 50.000 inhabitant equivalents each. The treatment capacity of these plants corresponds to $40 \%$ of Germany's total wastewater treatment capacity (Durth, Kolvenbach, \& Statistisches Bundesamt und DWA-Arbeitsgruppe KEK1.2 "Statistik," 2014). The new phosphorus recovery strategy does not affect these plants, although it does makes collaborations between plants more difficult. To promote phosphorus recovery by means other than in large plants and through application in agriculture, a series of technical and legal strategies should soon be introduced. These strategies should also consider the need for a combined or regional phosphorus recovery for the smaller plants. These innovations will of course imply a need for major adaptions to the German ordinance to ensure its suitability for use as a potential guideline for future legislation in Sweden.

Data present in literature has underlined the difficulties encountered in the Netherlands in implementing a policy strategy for phosphorus recovery. However, several pilot scale tests for phosphorus recovery are currently being conducted at wastewater treatment plants and mono-incinerators (Ruijter, 2018).

Since May 2014, the European commission has included phosphorus on the list of critical raw materials, leading to an increased focus on phosphorus recovery in some of the EU member states. In addition to phosphorus, sewage sludge also contains other valuables including potassium, nitrogen or metals. Since phosphorus recovery is not an indicator for the recovery of other valuables, none of the legislations examined is aimed at recovery of these valuables from sludge, thus implying that market demand will lead the potential extraction of other resources from sewage sludge. It is debatable whether a market demand for products obtained from sewage sludge may develop in the near future without a promoting legislation (Hukari, Hermann, \& Nättorp, 2016). The potential recovery, not only of phosphorus, but also of other nutrients and energy from sludge could be achieved by combining thermal and biological treatments with the goal of separating different fractions from sewage sludge. This could simplify the subsequent extraction of nutrients and better address the issue of pollutants. Due to the need however for a more concentrated technical effort, regional collaborations will prove crucial in setting up this type of extraction, together with other advanced sludge treatments.

\section{CONCLUSIONS}

All three countries investigated adhered to different strategies when setting limits for sewage sludge application on agricultural soils. Major differences are present in limit values for sewage sludge applied in agriculture - however, limit values for the presence of toxic elements in soils to which sewage sludge may be applied are comparable. The authors therefore question the utility of limit values in relation to health issues, particularly in view of other sources highlighting the minor role played by toxicology in the defining of limit values for sewage sludge (Ehlert et al., 2013; Langenkamp et al., 2001). Overall, all three coun- 
tries applied limit values as a tool to assist in steering the means of re-use and disposal of sewage sludge.

Although the Netherlands prohibited the application of sludge in agriculture more than 20 years ago, the average sludge in the Netherlands is still today less contaminated than average sludges in Sweden or Germany (Brown et al., 2015). Future research should be aimed at investigating why and how the Netherlands have succeeded in achieving a lower pollutant load in sewage sludge, and the knowledge exploited by other countries to reduce contamination of their sewage sludge.

In contrast to the Netherlands, Swedish ordinances permit the use of sewage sludge in low doses, providing for a system of voluntary deliberative certification; for this reason, application in agriculture is widely used. In contrast to the Netherlands and Germany, Sweden also uses large amounts (each approx. 25\%) of the produced sewage sludge in landfill covers and soil production (Svinhufvud, 2017). It is debatable however whether this process constitutes re-use, as reported by the European Commission (2017), particularly with regard to nutrient recovery.

While the new German ordinance places particular emphasis on new methods of phosphorus recovery, it still leaves options open for the continued operations of small plants and use of lower grade sludges in the absence of phosphorus recovery after 2032 . Indeed, application in agriculture will continue to be permitted. In this case, the intention of the policy makers is clear, although it may result in a loophole through which to bypass the new regulations (e.g. downgrading of sludges or downsizing of plants). It should be evaluated whether new rules for mixing of sludges and products from sludges, as well as transportation of sludges, might limit collaborations focused on the treatment of sewage sludge.

Despite the successful application of a series of technologies for use in phosphorus recovery, the legislative focus across the EU member states varies considerably (Abis, Calmano, \& Kuchta, 2018; Tsybina \& Wuensch, 2018; van Dijk, 2017). The performing of additional research in the field of nutrient recovery from sewage sludge and evaluation of potential related legislation will contribute towards setting clear goals and indicating a pathway towards the establishing of an EU-wide Directive. To date, the EU has issued a series of working documents on which to base a new Directive to replace the acknowledged outdated 1986 Directive (European Commission, 2010; European Union, 2000). The working documents focus on the agricultural usage of sewage sludge and new limit values, but not on phosphorus recovery (European Commission, 2010)

Lastly, it remains to be ascertained whether phosphorus should represent the sole resource to undergo recovery from sewage sludge, particularly as the issue of other resources present in sewage sludge are not considered in any legislation implemented throughout the three countries examined.

\section{ACKNOWLEDGEMENTS}

The work was carried out under the auspices of Graduate School in Energy Systems, financed by the Swedish
Energy Agency. Economic support from the Swedish Research Council Formas, within the national research program Sustainable Spatial Planning, is also gratefully acknowledged (dnr. 2018-00194).

\section{REFERENCES}

Abis, M., Calmano, W., \& Kuchta, K. (2018). Innovative technologies for phosphorus recovery from sewage sludge ash. Detritus - Volume 1, 1(1), 23. https://doi.org/10.26403/DETRITUS/2018.23

André, A., Sundin, A. M., Linderholm, L., Borbas, I., Svinhufvud, K., Eklund K., ... Rosenblom, T. (2016). Wastewater treatment in Sweden 2016. (Naturvårdsverket, Ed.). Retrieved from https://www.naturvardsverket.se/Documents/publikationer6400/978-91-620-8809-5.pdf?pid $=22471$

Aparicio, I., Santos, J. L., \& Alonso, E. (2009). Limitation of the concentration of organic pollutants in sewage sludge for agricultural purposes: A case study in South Spain. Waste Management, 29(5), 1747-1753. https://doi.org/10.1016/j.wasman.2008.11.003

Bengtsson, M., \& Tillman, A.-M. (2004). Actors and interpretations in an environmental controversy: the Swedish debate on sewage sludge use in agriculture. Resources, Conservation and Recycling, 42, 6582. https://doi.org/10.1016/j.resconrec.2004.02.004

Bergqvist, M., Gunnesby, U., Gårdstam, L., Hedlund, B., Karltorp, G., Kock, E., ... Åstrand, K. (2013). Hållbar återföring av fosfor. (Naturvårdsverket, Ed.), Rapport / Naturvårdsverket (Vol. 6580). Stockholm.

Brown, M., Tsiarta, C., Watson, S., \& Hudson, J. (2015). Final Implementation Report for the Directive 86/278/EEC on Sewage Sludge. Retrieved from https://ec.europa.eu/environment/archives/waste/ reporting/pdf/SS_dir_report_2010_2012.pdf

Bundesministerium für Umwelt. Klärschlammverordnung (AbfKlärV) (2015).

Bundesministerium für Umwelt. Verordnung zur Neuordnung der Klärschlammverwertung, 2017 Bundesgesetzblatt $\S$ (2017).

Bundesregierung. Bundes-Bodenschutz- und Altlastenverordnung ( BBodSchV ) (2017).

Bundesregierung. Verordnung über das Inverkehrbringen von Düngemitteln , Bodenhilfsstoffen, Kultursubstraten und Pflanzenhilfsmitteln ( Düngemittelverordnung - DüMV ), $1 \S$ (2017).

Bundesregierung. Verordnung über die Verwertung von Klärschlamm, Klärschlammgemisch und Klärschlammkompost (Klärschlammverordnung - AbfKlärV) (2017). Germany.

Council of the European Communities. Euopean urban waste water treatment directive (UWWTD) (91/271/EEC) of 21 May 1991 (1991). Retrieved from https://eur-lex.europa.eu/legal-content/ EN/TXT/PDF/?uri=CELEX:31991L0271\&from=EN

Council of the European Union. COUNCIL DIRECTIVE of 12 June 1986 on the protection of the environment, and in particular of the soil, when sewage sludge is used in agriculture, Offical Journal of the European Communities $§(1986)$.

Council of the European Union. COUNCIL DIRECTIVE of 12 June 1986 on the protection of the environment, and in particular of the soil, when sewage sludge is used in agriculture, Offical Journal of the European Communities $\S$ (1986). Retrieved from http://data.europa.eu/eli/dir/1986/278/oj

de Boer, M. A., Romeo-Hall, A., Rooimans, T., \& Slootweg, J. (2018) An Assessment of the Drivers and Barriers for the Deployment of Urban Phosphorus Recovery Technologies: A Case Study of The Netherlands. Sustainability, 10(6), 1790. https://doi.org/10.3390/ su10061790

Durth, A., Kolvenbach, F.-J., \& Statistisches Bundesamt und DWAArbeitsgruppe KEK-1.2 "Statistik." (2014). Abwasser und Klärschlamm in Deutschland - statistische Betrachtungen. Korrespondenz Abwasser, Abfall, 61(12), 1106-1112. https://doi. org/10.3242/kae2014.12.003

Ehlert, P. A. I., Posthuma, L., Römkens, P. F. A. ., Rietra, R. P. J. J., Wintersen, A. M., van Wijnen, H., ... Groenenberg, J. E. (2013). Appraising Fertilisers : Origins of current regulations and standards for contaminants in fertilisers (Working Document 336). Retrieved from http://www.wageningenur.nl/wotnatuurenmilieu/

European Commission. (2004). Implementation of Council Directive 91/271/EEC of 21 May 1991 concerning urban waste water treatment, as amended by Commission Directive 98/15/EC of 27 February 1998. Retrieved from https://eur-lex.europa.eu/legal-content/EN/TXT/PDF/?uri=CELEX:52004DC0248\&from=EN 
European Commission. (2010). Working Document Sludge and Biowaste.

European Commission. (2017). 9th Technical assessment on UWWTD implementation. Annex V: National chapters. Retrieved from http://ec.europa.eu/environment/water/water-urbanwaste/implementation/pdf/Annex V.pdf

European Union. (2000). Working Document on Sludge, 3rd draft (Vol. 80). Brussels.

eurostat. (2015a). Sewage sludge production and disposal from urban wastewater. (E. European Commission, Ed.). Luxembourg. Retrieved from https://ec.europa.eu/eurostat/tgm/graphCreator. do?tab $=$ graph $\& a=6 \& c p=$ noValue $\& c=1 \& d=0 \& h=1 \&$ geo $=2-39 \& x-$ $=g e o \& w w \_t p a r=2-7 \& y=w w \_t p a r \& l a n g u a g e=e n \& p c o d e=t e n 00030 \& p l-$ ugin=1 Y3 - 2019-01-09 M4 - Citavi

eurostat. (2015b). Sewage sludge production and disposal from urban wastewater. (E. European Commission, Ed.). Luxembourg

Government Offices of Sweden. (2018a). Giftfri och cirkulär återföring av fosfor från avloppsslam. Retrieved from https://www. regeringen.se/rattsliga-dokument/kommittedirektiv/2018/07/dir.201867/

Government Offices of Sweden. (2018b). Giftfri och cirkulär återföring av fosfor från avloppsslam.

Hukari, S., Hermann, L., \& Nättorp, A. (2016). From wastewater to fertilisers - Technical overview and critical review of European legislation governing phosphorus recycling. Science of The Total Environment, 542, 1127-1135. https://doi.org/10.1016/j.scitotenv.2015.09.064

Kelessidis, A., \& Stasinakis, A. S. (2012). Comparative study of the methods used for treatment and final disposal of sewage sludge in European countries. Waste Management (New York, N.Y.), 32(6), 1186-1195. https://doi.org/10.1016/j.wasman.2012.01.012 PM 22336390

Langenkamp, H., Part, P., Erhardt, W., \& Prüeß, A. (2001). Organic Contaminants in Sewage Sludge for Agricultural Use. Retrieved from https://ec.europa.eu/environment/archives/waste/sludge/pdf/ organics_in_sludge.pdf

LeBlanc, R. J., Matthews, P., \& Richard, R. P. (2008). Global atlas of excreta, wastewater sludge, and biosolids management. Proceedings of-IWA Conference-Moving forward Wastewater biosolids sustainability technical managerial and public synergy June. https://doi.org/10.1080/17405629.2013.793597
Malmqvist, P.-A., Kärrman, E., \& Rydhagen, B. (2006). Evaluation of the ReVAQ project to achieve safe use of wastewater sludge in agriculture. Water Science and Technology, 54(11-12), 129-135. https:// doi.org/10.2166/wst.2006.759

Naturvårdsverket. Kungörelse med föreskrifter om skydd för miljön, särskilt marken, när avloppsslam används i jordbruket (1994).

Naturvårdsverket. Statens naturvårdsverks föreskrifter om ändring i kungörelsen (SNFS 1994:2) med föreskrifter om skydd för miljön, särskilt marken, när avloppsslam används i jordbruket (1998).

Naturvårdsverket. Kungörelse med föreskrifter om skydd för miljön, särskilt marken, när avloppsslam används i jordbruket (2001). Sweden.

Naturvårdsverket. Kungörelse med föreskrifter om skydd för miljön särskilt marken, när avloppsslam används i jordbruket (2001) Sweden. Retrieved from http://www.naturvardsverket.se/Documents/foreskrifter/nfs1994/snfs1994-02k.pdf

Oberg, G., \& Mason-Renton, S. A. (2018). On the limitation of evidence-based policy: Regulatory narratives and land application of biosolids/sewage sludge in BC, Canada and Sweden. Environmental Science and Policy, 84, 88-96. https://doi.org/10.1016/j. envsci.2018.03.006

Ruijter, J. A. (2018). Dutch Experience of sludge management and P-recovery pathways Content 1 . Sewage water treatment in NL 2 Sludge management.

Svinhufvud, K. (2017). Phosphorus: Strategies and Reuse Initiatives in Sweden. (Naturvårdsverket, Ed.). Vilnius.

Tsybina, A., \& Wuensch, C. (2018). Analysis of Sewage Sludge Therma Treatment Methods in the Context of Circular Economy, 02, 3-15.

van Aaken, L. (2017a). Klärschlammverordnung verkündet. (B. K. e.V., Ed.).

van Aaken, L. (2017b). Klärschlammverordnung verkündet. (B. K. e.V. Ed.). Retrieved from https://www.kompost.de/fileadmin/user_upload/Dateien/HUK_aktuell/2017/H_K-03-2017.pdf

van Dijk, K. (2017). Nutrient recovery from wastewater: opportunities and challenges of EU regulatory context. Retrieved from www. phosphorusplatform.eu

Zachrisson, N. (2019). Slamförbud riskerar spridning i det fördolda. Retrieved November 13, 2019, from https://sverigesradio.se/sida/ artikel. aspx?programid $=406 \&$ artikel $=7014613$ 